American Journal of Environmental Sciences 8 (2): 104-116, 2012

ISSN 1553-345X

(C) 2012 Science Publications

\title{
Impact of Shrimp Farm Effluent on Water Quality in Coastal Areas of the World Heritage-Listed Ha Long Bay
}

\author{
${ }^{1,2}$ Thuyet D. Bui, ${ }^{1}$ Jim Luong-Van and ${ }^{3}$ Chris M. Austin \\ ${ }^{1}$ School of Environmental and Life Sciences, \\ Charles Darwin University, Darwin, NT0909, Australia \\ ${ }^{2}$ Center for Environment and Disease Monitoring in Aquaculture, \\ Research Institute for Aquaculture No1, Tu Son, Bac Ninh, Vietnam \\ ${ }^{3}$ School of Science, Monash University, Jalan Lagoon Selatan, \\ Bandar Sunway, 46150 Selangor, Malaysia
}

\begin{abstract}
Problem statement: Shrimp farming has rapidly developed in coastal areas of the World Heritage-listed Ha Long Bay since the last decade. Effluent discharged from shrimp farms with high levels of nutrient waste may cause eutrophication in receiving waterways. Therefore, assessing water quality at tidal creeks receiving shrimp farm effluent in coastal areas of Ha Long Bay supports environmental protection and decision making for sustainable development of the region. Approach: Water samples were collected at 3 different locations for spatial assessment: inside sections of creeks directly receiving farm effluent (IEC), from main creeks adjacent to points of effluent discharge outside concentrated shrimp farms (OEC) and a few kilometers away from shrimp farm (ASF). Samples were taken on 3 occasions for temporal assessment. Parameters related to nutrient waste from shrimp farms, including: Total Ammonia Nitrogen (TAN), Nitrite-Nitrogen (NO2-N), Nitrate-Nitrogen (NO3-N), Total Phosphorus (TP), Dissolved Orthophosphate (PO4-P), Biochemical Oxygen Demand (BOD), Chemical Oxygen Demand (COD), Total Suspended Solid (TSS), Chlorophyll-a (Chl-a), Temperature, Salinity, $\mathrm{pH}$ and Dissolved Oxygen (DO) were determined using standard methods. Results: There were statistically significant differences in the concentrations of TAN, NO2-N, NO3N, TP, PO4-P, BOD, COD and Chl-a among IEC, OEC, ASF and the levels of these parameters increased after shrimp crops, especially after the main shrimp crop of the season in North Vietnam. The concentrations of TAN, NO3-N, TP, BOD, COD, Chl-a, TSS at IEC sites were higher than recommended for protecting aquatic ecosystems. Principal Component Analysis (PCA) efficiently summarized patterns of co-variation in water quality parameters among locations and study times. Conclusion/Recommendations: The findings of this study indicate that greater awareness of the environmental impacts of shrimp farms is required if this industry is to be sustainable and if the highly valued marine ecosystem of Ha Long Bay is to be protected for the future.
\end{abstract}

Key words: Nutrient waste, eutrophication, Principal Component Analysis (PCA)

\section{INTRODUCTION}

Shrimp farming has rapidly expanded over the last two decades, with the total world cultured shrimp production reaching 3.4 million tonnes, valued at over 14 billion USD in 2008 (FAO, 2010). However, the industry is receiving increasing criticisms as effluent discharged from shrimp farms can be a major source of pollution in estuarine and marine ecosystems (Dierberg and Kiattisimkul, 1996; Flaherty and Karnjanakesorn, 1995; Graslund et al., 2003; Paez-Osuna, 2001; PaezOsuna et al., 1998; 2003; Senarath and Visvanathan, 2001). Pollution from shrimp farms is in the form of waste feed, shrimp faeces and excreta that can lead to nutrient enrichment, eutrophication and increased suspended solids in receiving waters (Boyd and Green, 2002; Jackson et al., 2003; Senarath and Visvanathan, 2001).

Studies have revealed that a large portion of input nitrogen and phosphorus into shrimp ponds as feed is not converted to shrimp biomass, but is released into the environment (Briggs and Funge-Smith, 1994; Funge-Smith and Briggs, 1998; Jackson et al., 2003; Martin et al., 1998; Paez-Osuna et al., 1997; TeichertCoddington et al., 2000; Thakur and Lin, 2003; Xia et al., 2004; Paez-Osuna and Ruiz-Fernandez, 2005); and 
Am. J. Environ. Sci., 8 (2): 104-116, 2012

therefore the waters receiving farm effluent often have elevated levels of nutrients leading to excess primary productivity (Anh et al., 2010; Biao et al., 2004; Costanzo et al., 2004; Guerrero-galvan et al., 1998; Lemonnier and Faninoz, 2006; Jones et al., 2001; McNevin, 2004; Nguyen, 2008; Rodriguez-Gallego et al., 2008; Samocha and Lawrence, 1995; Samocha et al., 2004; Islam et al., 2004; Trott and Alongi, 2000; Tookwinas, 1998). The temporal and spatial scale of such impacts, however, vary considerably depending on farm management practices, the number, scale and proximity of shrimp farms, farm flushing rates and carrying capacity of receiving water bodies (Senarath and Visvanathan, 2001). Hence, spatial and temporal assessment and monitoring of coastal aquatic environments in shrimp farming areas are essential if estuarine and marine ecosystems are to be protected and economic development of coastal areas is to be sustainable (Boyd and Green, 2002).

As with many other tropical and sub-tropical countries with an extensive coastal line, shrimp farming activity has developed rapidly in Vietnam including in the coastal areas of the World Heritage-listed Ha Long Bay, Quang Ninh province (CTCC, 2008; DoF Quang Ninh, 2001; 2005). Annual cultured shrimp product for the Quang Ninh province increased gradually from 903 tonnes in 2001, reaching a peak of 7126 tonnes in 2007 and has slightly declined since then (GSOV, 2009), of which nearly half is from Ha Long Bay region. In fact, self pollution and sustainability is a critical issue for the Vietnamese shrimp farming as many farms supply and discharge water from the same creek system. In addition, effluent released from shrimp farms together with other activities (agriculture, mining, tourism, fish cage culture, industry and sewerage) potentially contributes to a decline in water quality in coastal and marine ecosystems of the World Heritage-listed Ha Long Bay, a region which attracts millions of national and international visitors each year (PCQNP, 2010). This study, therefore, aims to investigate the impacts of effluent discharged from shrimp farms on water quality of receiving waterways in the $\mathrm{Ha}$ Long Bay area, thereby contributing essential information for environmental protection, sustainable coastal development and management in the region.

\section{MATERIALS AND METHODS}

Study sites and sampling plan: Two study sites were chosen in coastal areas of Ha Long Bay (N20 $53^{\prime} 60^{\prime}$ ', E107 5'60') (UNESCO, 2010) in concentrated shrimp farming areas with independent creek systems (Bac Cua Luc and Yen Hung) (Fig. 1).
Water samples were collected at 3 different locations for spatial assessment of water quality: inside channels or creeks receiving effluent directly from shrimp farms (IEC), from main creeks adjacent to points of effluent discharge outside shrimp farms (OEC) and a few kilometers away from shrimp farms (ASF) as reference sites (Fig. 1). Geographical coordinates of sampling sites were marked using a Global Positioning System (GPS) for re-monitor and future work with maps and images.

In order to investigate temporal impacts of shrimp farming activities, water samples were collected on 3 occasions in 2009: before the shrimp growing season, when shrimp farms have been idle during the winter season (end of winter, dry season-March 2009)-T0; after the harvest of first shrimp crop (during the summer, raining season-August 2009)-T1 and after the harvest of second shrimp crop (beginning of the winter, dry season-December 2009)-T2. Sampling was carried out under the same tidal conditions (middle to low tide of spring tide) (US-EPA, 2001).

Assessment of water quality: Sampling procedures and analyses were based on "Standard Methods for the Examination of Water and Wastewater" (Clesceri and Franson, 1998) and "Nutrient Criteria Technical Guidance Manual Estuarine and Coastal Marine Waters" (US-EPA, 2001). Parameters for water quality assessment comprised: water temperature, salinity, $\mathrm{pH}$, Dissolved Oxygen (DO), Total Ammonia Nitrogen (TAN), nitrite nitrogen (NO2-N), nitrate nitrogen (NO3$\mathrm{N})$, dissolved orthophosphate (PO4-P), Total Phosphorus (TP), Chemical Oxygen Demand (COD), Biochemical Oxygen Demand (BOD5), Total Suspended Solid (TSS) and chlorophyll-a (Chl-a) (ANZECC-ARMCANZ, 2000; Boyd and Green, 2002; US-EPA, 2001; EPA-Victoria, 2001). Field measurements consisted of water temperature, salinity, $\mathrm{pH}$ and $\mathrm{DO}$.

Salinity was measured by salinity refractometer (ATAGO S/Mill-E); $\mathrm{pH}$ water was measured by $\mathrm{pH}$ meter (WTW 315i); DO and water temperature were measured by DO meter (YSI 55). Two $1000 \mathrm{~mL}$ plastic bottles were filled fully with water from each sample station, labeled and stored on ice for transport to the laboratory for water quality analysis.

Water samples were analyzed, using spectrophotometric determination, for TAN by phenate method (Clesceri and Franson, 1998); NO2-N by diazotization method (Clesceri and Franson, 1998); NO3-N by cadmium reduction, diazotization method (Clesceri and Franson, 1998); PO4-P by ascorbic acid method (Clesceri and Franson, 1998); TP by persulfate digestion method for preliminary step and then ascorbic acid method (Clesceri and Franson, 1998); Chl-a by $\mathrm{GF} / \mathrm{C}$ glass fiber filtration, acetone extraction (Clesceri and Franson, 1998). 
Am. J. Environ. Sci., 8 (2): 104-116, 2012

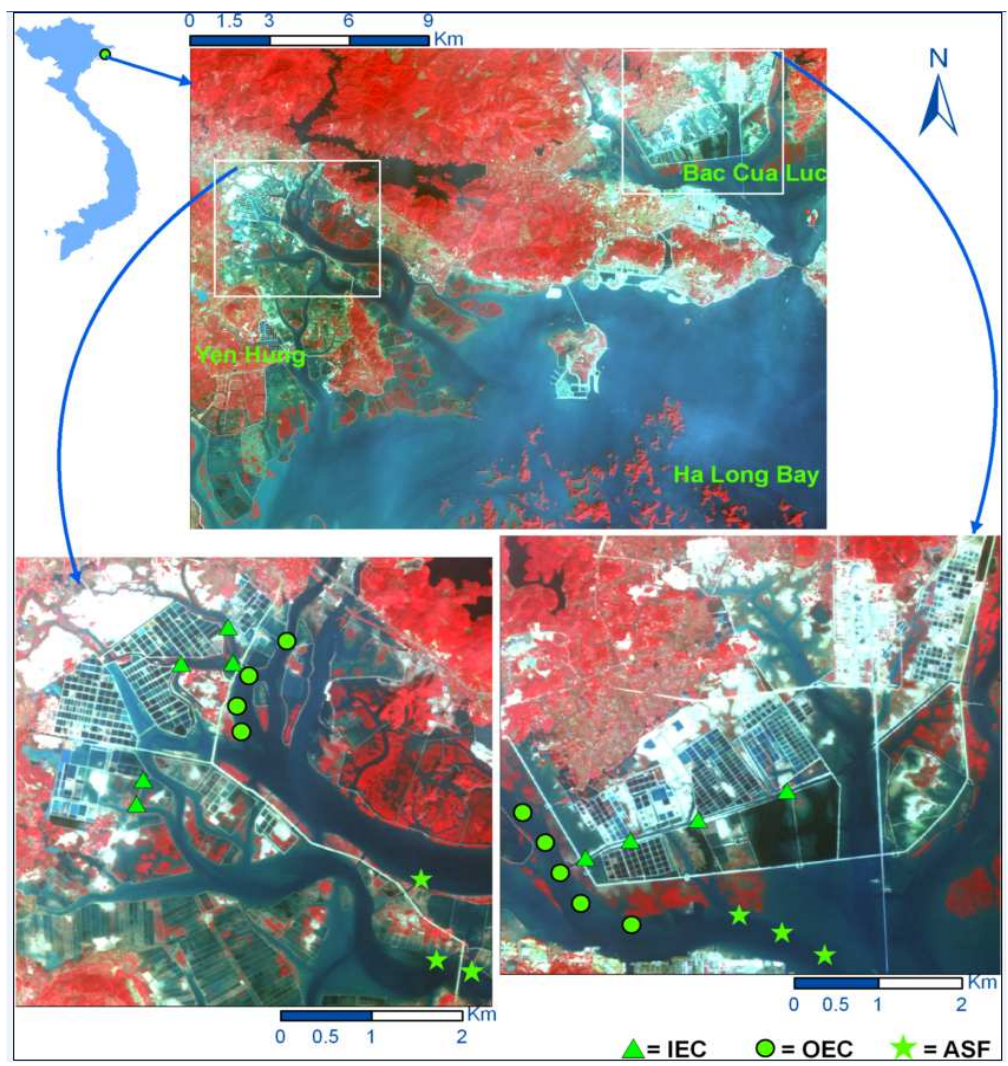

Fig. 1: Study area within the coastal zone of Ha Long Bay and enlargements showing sampling sites within the Yen Hung and Bac Cua Luc creek systems. Triangles, circles and stars are sampling sites located inside effluent channels or creeks (IEC), outside effluent creeks (OEC) and away from concentrated shrimp farms (ASF), respectively. (ALOS image captured in Oct.2008)

COD was analyzed by alkaline permanaganate oxidation method (Doan, 2001); BOD5 by incubating at $20^{\circ} \mathrm{C}$ for 5 days with the measurement of dissolved oxygen before and after incubation (Clesceri and Franson, 1998); TSS by GF/C glass fiber filtration and dried at $103^{\circ} \mathrm{C}$ for $1-2 \mathrm{~h}$ and weighed (Clesceri and Franson, 1998).

Data analyses: Water quality data were recorded, summarized and analyzed using Microsoft Excel 2007 and PASW Statistics 18 (Predictive Analytics Software, formerly named SPSS) (Field, 2009).

As the two sampling areas (Yen Hung and Bac Cua Luc) are not far from each other (Fig. 1) and preliminary data analayses with Mann-Whiteney U test of the two data sets of IEC/OEC/ASF measurements between these two areas showed no significant differences $(p>0.05)$ for most of variables under study, data from these two areas were pooled for statistical analyses. Shapiro-Wilk tests and graphical plots were used to explore the distribution of data. Levene's test was used to test homogeneity of variances. Univariate outliers were detected by boxplots; multivariate outliers were identified by Mahalanobis distances. Extreme outliers were checked for data entry or other errors and extreme outliers were excluded from statistical analyses to avoid spurious statistical results in parametric analyses (Hibbert and Gooding, 2006; Quinn and Keough, 2002; Zar, 1999; Zuur et al., 2007).

One way ANOVA was used to test for significant differences $(\mathrm{p}<0.05)$ of marginal means of water quality variables at 3 different locations (IEC, OEC, ASF) for each study time. Post hoc analysis with Tukey' $\mathrm{s}$ test and Bonferroni corrections (if equal variances assumed) and Tamhane and Games-Howell tests (if equal variances not assumed) were used to identify where the differences lay (Field, 2009).

Repeated Measures ANOVA (RM-ANOVA) $(p<0.05)$ was used for temporal analysis of variables at T0, T1, T2 as this involved time series measurements from the same sites (Field, 2009; Ennos, 2007). Box's $\mathrm{M}$ test was used to determine if multivariate (time series and location factors) rather than univariate (only 
time series) tests could be applied in RM-ANOVA analysis. In cases where multivariate test cannot be applied due to violation of its assumption, data were split into spatial groups (IEC, OEC, ASF) for the comparison of means over the study time series, using separated RM-ANOVA analyses for univariate tests. Mauchly's Test tests for sphericity within-subjects for repeated measurement data (T0, T1, T2); if sphericity was violated, epsilons of Greenhouse-Geisser, HuynhFeldt and Lower-bound were used for the adjustment and interpretation of statistical results. If there was a difference, a follow-up pairwise comparison using the Bonferroni correction and LSD test were used to identify where the differences in the time series lay (Field, 2009). Splitting data into location groups and then running separated RM-ANOVA analysis for each IEC, OEC, ASF location were not only used to deal with the violation of multivariate test as mentioned above, but also used to identify where the differences of the interaction between times and locations in the multivariate tests lay or to identify changes at each location over the study times.

For variables that did not fulfill the normality assumptions, even after testing different transformations, non-parametric tests were applied. Kruskall-Wallist test $(\mathrm{p}<0.05)$ was used to identify differences in the medians of measurements among IEC, OEC, ASF locations for each sampling time. Friedman test $(p<0.05)$ was used to investigate the differences in the medians of measurements between T0, T1, T2 study times for each location (Ennos, 2007; Graham, 1993; Quinn and Keough, 2002; Zar, 1999). In order to provide an overview of the patterns of variation in water quality parameters within and between sites and among sampling times, a Principal Component Analysis (PCA) was carried out (Quinn and Keough, 2002; Zuur et al., 2007).

\section{RESULTS}

Temperature and salinity: Water temperature varied between sampling times, but showed only limited variation among study sites, within and between locations (Fig. 2a). RM-ANOVA analysis found that there were significant differences in the mean temperature among study times, with average temperature ranging from $19.1-30.9^{\circ} \mathrm{C}$. No differences were apparent between locations.

Salinity was highest at T0, T2 and lowest at T1 during the wet season (Fig. 2b), with the average salinity varying from $16-31 \%$. There were no significant differences in the mean salinity among IEC, OEC, ASF locations at most study times, except for the first observation (T0) for which salinity was significantly higher at ASF sites. Results from the RMANOVA analysis showed significant differences in the mean salinity among study times.
Dissolved oxygen and pH: Dissolved oxygen levels varied among study times with lowest average DO measured at T1 $\left(6.41 \mathrm{mg} \mathrm{L}^{-1}\right)$ compared to T0 $(7.05 \mathrm{mg}$ $\left.\mathrm{L}^{-1}\right)$ and $\mathrm{T} 2\left(7.15 \mathrm{mg} \mathrm{L}^{-1}\right)$. DO levels at IEC were generally lower than those found at OEC and ASF (Fig. 2c). ANOVA analysis indicated that DO concentrations were significantly different among IEC, OEC, ASF locations at $\mathrm{T} 0$, but were not significantly different at

T1, T2. RM-ANOVA analysis showed significant differences in the mean DO in study creeks between study times.

$\mathrm{pH}$ values showed a general increase from T0-T2 with average $\mathrm{pH}$ ranging from 7.35-7.97 (Fig. 2d). There were no significant differences in the mean $\mathrm{pH}$ among IEC, OEC, ASF locations at T0, T2; however, after the first shrimp crop (T1), $\mathrm{pH}$ values at IEC were significant lower than those at OEC and ASF. RMANOVA analysis indicated that $\mathrm{pH}$ values were significantly different among study times, with an interaction between study time and location.

Dissolved Inorganic Nitrogen (DIN): Total Ammonia Nitrogen (TAN) varied from $0.005 \mathrm{mg} \mathrm{L}^{-1}$ (ASF, T2) to $0.758 \mathrm{mg} \mathrm{L}^{-1}$ (IEC, T0) and the mean values were generally highest at IEC and lowest at ASF at all study times (Fig. 3a). Before shrimp crop (T0), ANOVA analysis indicated no significant differences in the mean TAN among IEC, OEC, ASF locations. After shrimp crops (T1, T2), concentrations of TAN were significant different among IEC, OEC, ASF locations. Results from RM-ANOVA analysis showed that TAN concentrations. in study creeks were not significantly different between $\mathrm{T} 0$ and T1. However, a significant difference in TAN concentrations was detected between $\mathrm{T} 1$ and $\mathrm{T} 2$.

Nitrite-nitrogen (NO2-N) ranged from 0.002-0.081 $\mathrm{mg} \mathrm{L}^{-1}$ and was highest at IEC sites, especially after shrimp crop (T1, T2) and lowest at ASF sites (Fig. 3b). ANOVA analysis indicated that there were significant differences in NO2-N concentrations between ASF and IEC, OEC (sites surrounding shrimp farms), except for those of ASF and OEC at T2. At T0 and T1, NO2-N levels in creeks surrounding shrimp farms (IEC, OEC) were not significantly different; however, at T2, a significant difference was found. RM-ANOVA analysis showed significant differences in the mean NO2-N at IEC before and after shrimp crops, but no significant difference was detected between $\mathrm{T} 1$ and $\mathrm{T} 2$. However, at OEC and ASF locations, NO2-N levels were significant higher at $\mathrm{T} 1$ in comparison to T0, T2.

The highest concentration of nitrate-nitrogen (NO3-N) observed was $0.456 \mathrm{mg} \mathrm{L}^{-1}$ (IEC, T2), the lowest was $0.010 \mathrm{mg} \mathrm{L}^{-1}$ (OEC, T0), with mean values increasing after shrimp crops (T1, T2) (Fig. 3c). 


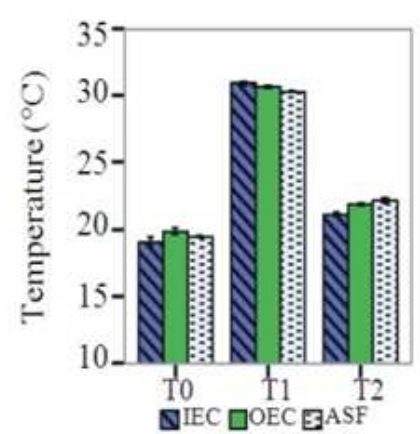

(a)

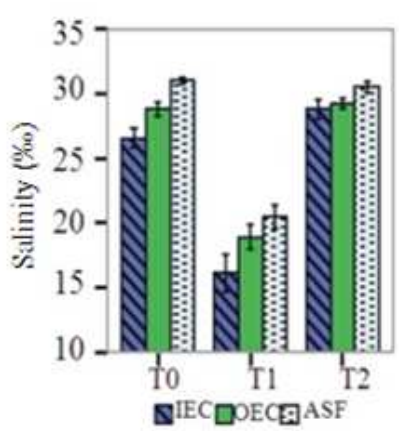

(b)

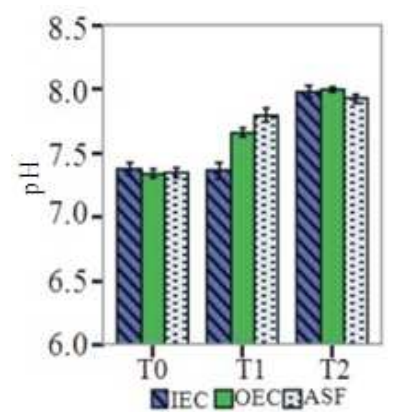

(d)

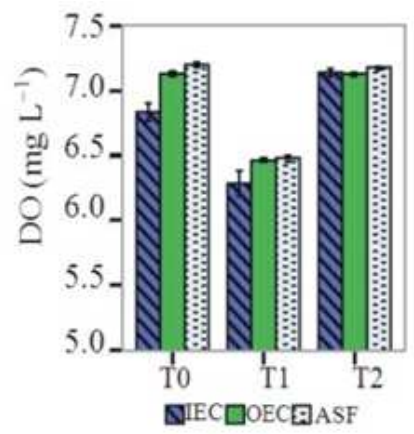

(c)

Fig. 2: Mean values and standard error of the mean for water temperature (a), salinity (b), DO (c) and pH (d) in IEC, OEC, ASF locations in Ha Long area at T0, T1, T2

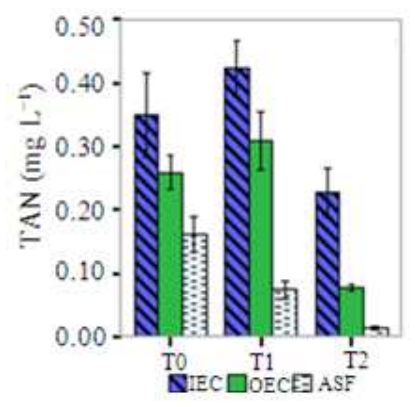

(a)

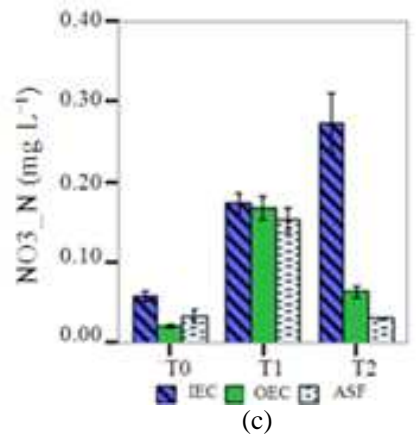

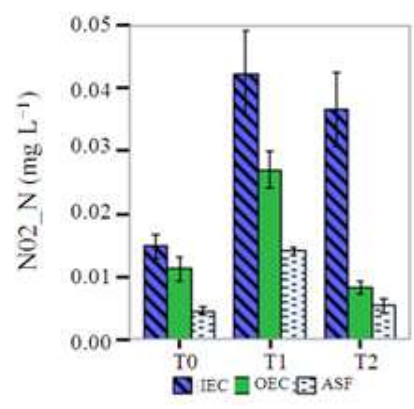

(b)

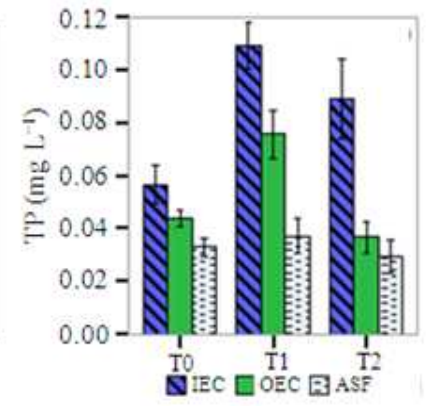

(d)

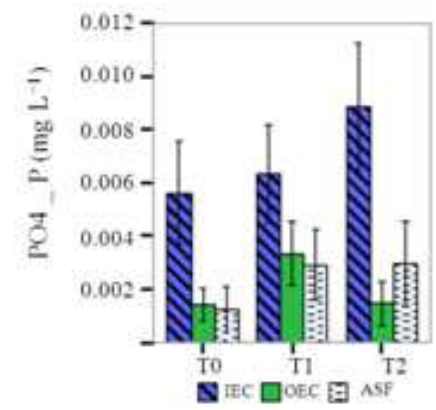

(e)

Fig. 3: Mean values and standard error of the mean for TAN (a), NO2-N (b), NO3-N (c), TP (d) and PO4-P (e) in IEC, OEC, ASF locations in Ha Long area at T0, T1, T2 
NO3-N means at IEC were significantly higher than those found at OEC and ASF at T0 and T2; however, after first shrimp crop (T1), no significant differences were observed for NO3-N levels among IEC, OEC, ASF location (0.174, 0.166, $0.152 \mathrm{mg} \mathrm{L}{ }^{-1}$, respectively). RM-ANOVA analysis indicated that the mean NO3-N was significantly lower before shrimp crop (T0) compared to after shrimp crops (T1, T2). At OEC and ASF locations, the mean NO3-N at T1 was significantly higher than those found at T2.

Total Phosphorus (TP) and dissolved orthophosphate (PO4-P): Total phosphorus ranged from $0.005-0.162 \mathrm{mg} \mathrm{L}^{-1}$, with concentrations surrounding shrimp farms (IEC, OEC) generally increasing after shrimp crops (T1, T2) (Fig. 3d). Before shrimp crop (T0), mean TP at IEC $(0.057 \mathrm{mg}$ $\left.\mathrm{L}^{-1}\right)$ was not significantly different from OEC (0.044

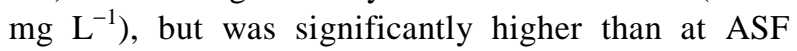
(0.033 $\left.\mathrm{mg} \mathrm{L}^{-1}\right)$. After shrimp crops, TP concentrations were significantly different among IEC, OEC, ASF locations, except for between OEC and ASF at T2.

RM-ANOVA analysis indicated that for creeks surrounding shrimp farms (IEC, OEC) TP concentrations at T0 were significant lower than those measured at T1, but not different to those at T2. TP concentrations at ASF did not differ statistically among study times.

The means of dissolved orthophosphate were highest at IEC (0.006-0.009 $\left.\mathrm{mg} \mathrm{L}^{-1}\right)$ and lowest at OEC and ASF (0.001-0.003 $\mathrm{mg} \mathrm{L}^{-1}$ ) (Fig. 3e). Kruskall-Wallis test showed that there were significant differences of PO4-P concentrations among IEC, OEC and ASF locations at T0 and T2, but not at T1. Pairwise comparisons indicated that PO4-P concentrations at IEC were significant higher than those at OEC and ASF at T0 and at OEC at T2. Friedman tests showed no significant differences in PO4-P concentrations among study times.

Biochemical Oxygen Demand (BOD5) and Chemical Oxygen Demand (COD): Means of BOD5 at IEC increased from T0 $\left(3.47 \mathrm{mg} \mathrm{L}^{-1}\right)$ to $\mathrm{T} 2\left(5.37 \mathrm{mg} \mathrm{L}^{-1}\right)$ while those at OEC and ASF showed limited variation over time (Fig. 4a). ANOVA analysis indicated significant differences in the mean BOD5 with IEC> OEC> ASF. RM-ANOVA analysis showed that means of BOD5 were significantly higher after shrimp crops at IEC, but that no significant differences were apparent at OEC and ASF among study times.
There were significant differences in the mean COD among IEC, OEC, ASF locations at all study times with IEC> OEC> ASF (Fig. 4b). RM-ANOVA analysis showed that there were significant differences in mean COD between study times in surrounding concentrated shrimp farms (IEC, OEC), but that there were no significant differences in mean COD at ASF among study times.

Total Suspended Solids (TSS) and Chlorophyll-a (Chl-a): The mean TSS in IEC increased from T0 (122 $\left.\mathrm{mg} \mathrm{L}^{-1}\right)$ to $\mathrm{T} 2\left(147 \mathrm{mg} \mathrm{L}^{-1}\right)$ while those of OEC and ASF showed little difference between T0 (121 mg L $\left.{ }^{-1}\right)$ and T1 (117 $\left.\mathrm{mg} \mathrm{L}^{-1}\right)$ with higher values observed at T2 (137 $\mathrm{mg} \mathrm{L}^{-1}$ ) (Fig. 4c). ANOVA analysis indicated that TSS levels among IEC, OEC, ASF locations were not significantly different at $\mathrm{T} 0$ and $\mathrm{T} 2$, but were significantly different at T1 (IEC> OEC> ASF). RMANOVA analysis showed that there were significant differences in the mean TSS among study times with T2 having the highest values.

Chl-a values showed considerable variation both within and between study times ranging from 0.535 $36.086 \mu \mathrm{g} \mathrm{L}^{-1}$. The most substantial variation was between before shrimp crop (T0) and after shrimp crops (T1, T2), especially at the IEC location (Fig. 4d). ANOVA analysis showed significant differences in the means of Ch-a among IEC, OEC, ASF locations at all study times. While the only non significant difference of Chl-a levels between IEC $\left(3.505 \mu \mathrm{g} \mathrm{L}^{-1}\right)$ and OEC (2.079 $\mu \mathrm{g} \mathrm{L}^{-1}$ ) was at $\mathrm{T} 0$, the pattern of variation was the same among study sites with Chl-a levels at IEC significant higher than those found at OEC and ASF. RM-ANOVA analysis showed that there were no significant differences in Chl-a at ASF over the study times, but that there were significant differences between observations for Chl-a levels in creeks surrounding shrimp farms (IEC, OEC) with by far the highest values recorded at IEC.

Principal Component Analysis (PCA) for multivariate parameters at sampling sites: The PCA biplot (Fig. 5a) shows the correlation among study parameters as well as their relationships to component scores for sampling sites at the first two dimensions (accounting for $65.8 \%$ of the total variation). The first dimension of variation accounts for $44.8 \%$ of the total variation and mainly represents for parameters relating to shrimp farm effluent nutrients (i.e., NO2-N, NO3-N, TP, COD, BOD5, Chl-a). 
Am. J. Environ. Sci., 8 (2): 104-116, 2012

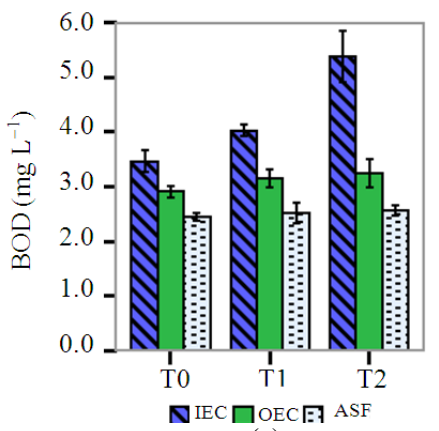

(a)

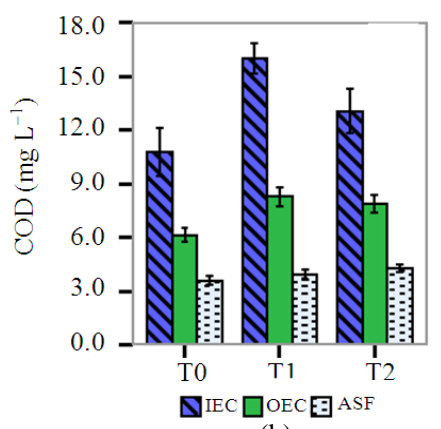

(b)

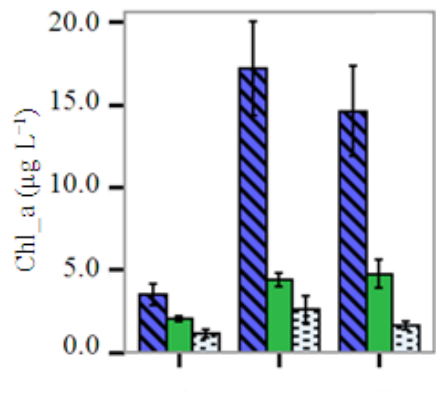

बIEC ПOEC П ASF

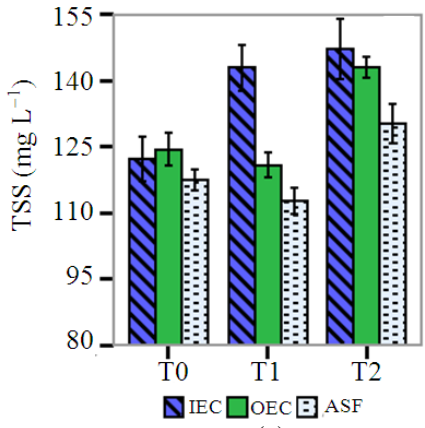

(c)

(d)

Fig. 4: Mean values and standard error of the mean for BOD5 (a), COD (b), TSS (c) and Chl-a (d) in IEC, OEC, ASF locations in Ha Long area at T0, T1, T2

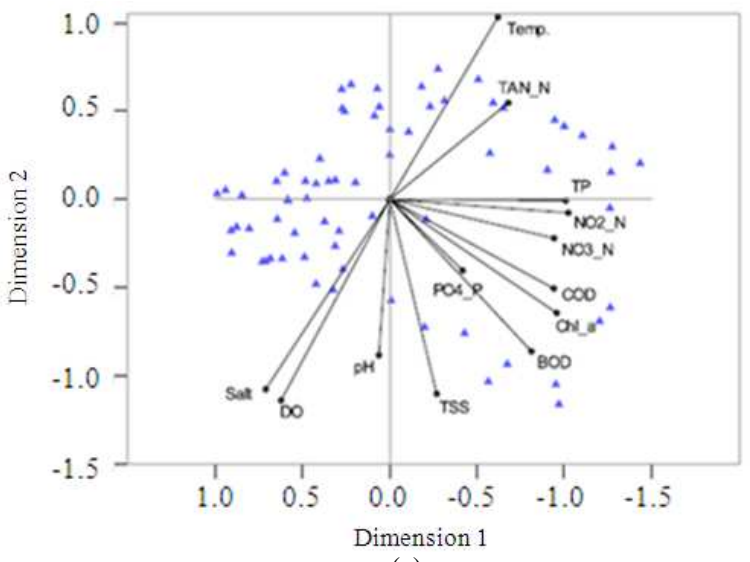

(a)

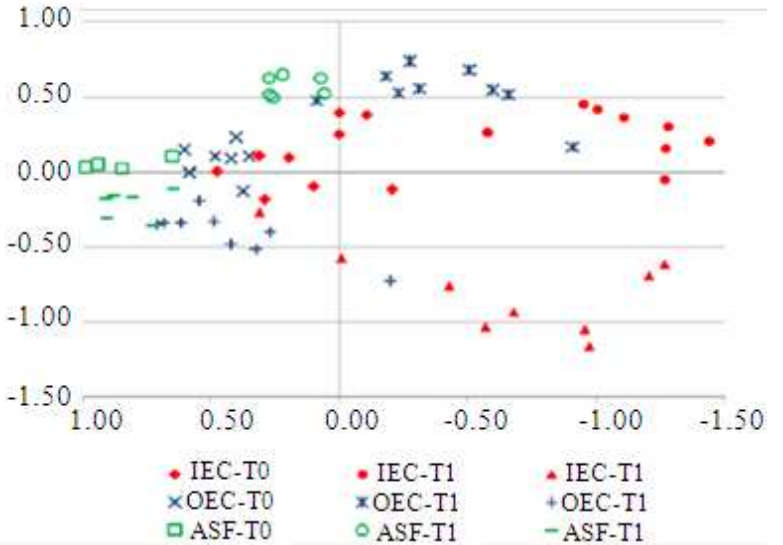

(b)

Fig. 5: PCA biplot for multivariate parameters and sampling sites in Ha Long (a); PCA distance plot for sampling sites in IEC, OEC, ASF locations at T0, T1, T2 in Ha Long (b)

Dimension 2, accounting for $21 \%$ of the total variation, mainly represents physical parameters such as temperature and TSS and as well salinity and DO. Component scores for sampling sites in Fig. 5a classified by location (IEC, OEC, ASF) and time (T0, $\mathrm{T} 1, \mathrm{~T} 2)$ are given in Fig. 5b. In the first dimension, most of sampling sites at IEC, especially after shrimp crops (T1, T2), have mostly positive scores with wide variability indicating high values for variables related to nutrients. Conversely, most of sampling sites at ASF have negative score indicating low nutrient levels. Water quality at OEC sites was similar to ASF sites at $\mathrm{T} 0, \mathrm{~T} 2$, but was different at $\mathrm{T} 1$ with higher loadings on dimension 1 . The second dimension reveals seasonal 
effects on water quality. Samples from T1 (summer) had positive scores, which contrasted with $\mathrm{T} 2$ with negative scores (lower temperature while higher salinity and DO level). Scores for later winter before shrimp crop (T0) was mostly intermediate.

\section{DISCUSSION}

Water quality in coastal creeks of Ha Long Bay was found to show significant spatial and temporal changes which correlated with shrimp farming practices in the area. The multivariate statistical analyses neatly summarizes the high levels of pollution (nutrient enrichment) produced by shrimp farming activities and how this can impact the quality of receiving waters immediately adjacent to farms but with these effects dissipating downstream from effluent discharge points (Fig. 5). The significance of the variation of the individual water quality parameters presented in this study is discussed in detail below.

Water temperature and salinity: Significant variation in water temperature was found in this study due to seasonal changes in the shallowwaters sampled in north Vietnam. Similarly, changes in salinity in study creeks between sampling times were also related to seasonal effects with lower salinity during the rainy season (T1-August 2009) and higher levels during dry seasons (T0, T2).

Dissolved oxygen: DO is a vital parameter for assessing the living conditions for aerobic aquatic organisms as well as other chemical processes within aquatic ecosystem (Boyd and Green, 2002; Boyd and Tucker, 1998). DO concentration in waters is dependent on the transfer rate from the atmosphere (stagnant or moving water), water temperature, salinity, biological activities (respiration and photosynthesis) and microbial activities (ANZECC-ARMCANZ, 2000; Boyd and Tucker, 1998). One of the most critical issues related to effluent discharged from shrimp farms is its low DO level as this is associated with high concentration of organic matter which consumes oxygen in the decomposition processes in receiving waterways. In this study, DO concentrations were generally higher than the suggested level for coastal water quality monitoring in shrimp farming areas by Boyd and Green (2002) (> 5-6 $\mathrm{mg} \mathrm{L}^{-1}$ ), possibly because the creeks in this study were shallow and had flowing water. The reduced levels of DO during summer (T1) is most likely due to the increase in water temperature as well as DO consumption for biological activities (Boyd and Tucker, 1998). Lower DO concentrations as well as higher BOD levels inside effluent creeks (IEC) showed that shrimp farm effluent is likely to impact receiving waterways in terms of organic matter pollution.

pH: The $\mathrm{pH}$ value represents an index of the acidity and alkalinity of water and its changes may affect chemical processes, physiological functioning (i.e., enzymes, membrane processes) of biota and toxic levels of toxic compounds (i.e., ammonia) (ANZECCARMCANZ , 2000; Boyd and Tucker, 1998). Perhaps the most critical point related to changes in $\mathrm{pH}$ water surrounding coastal shrimp farms is the construction of shrimp farms on acid sulfate soil and the use of limes, chemicals during farm operation. Even though $\mathrm{pH}$ values in this study fluctuated among study sites and over time, these levels fall into the acceptable range (6.0-9.0) for estuarine and marine ecosystems (Boyd and Green, 2002).

Total ammonia nitrogen: Ammonia in water is the principal nitrogenous waste product excreted by aquatic animals and released from decomposing nitrogencontaining organic matters by microbial activities and it is assimilated by algae or transformed into nitrite and then nitrate forms in the water column. Ammonia exits in two forms of the ammonium ion (NH4+) (plant nutrient) and unionized ammonia (NH3) (toxic to aquatic animals) and the equilibrium of these forms varies depending on water $\mathrm{pH}$, temperature and salinity (Boyd and Tucker, 1998). High concentrations of TAN in shrimp farm effluent and receiving waterways are the result of shrimp excretion and waste feed decomposition; therefore, Boyd and Green (2002) suggested that TAN should be considered as a key indicator of pollution in coastal shrimp farming areas. In this study, TAN concentrations in ASF were within the allowable limit of $<0.1 \mathrm{mg} \mathrm{L}^{-1}$ for coastal water quality in aquaculture and preservation zones (MONRE, 2008), except for the first observation (T0) (Fig. 3a). Higher levels of TAN at ASF at T0 may have resulted from lower algae density and nitrification process in the cool season and lower flushing rate during the dry season (Boyd and Tucker, 1998). TAN levels at IEC and OEC location were higher than those found in studies of Costanzo et al. (2004) and McNevin (2004), but lower than those reported in Samocha et al. (2004) and Nguyen (2008); and higher than suggested for national standards $\left(<0.1 \mathrm{mg} \mathrm{L}^{-1}\right)$ for coastal water quality in aquaculture and preservation zones (MONRE, 2008). The higher levels of TAN in creeks adjacent to shrimp farms, especially after shrimp crops, in this study showed that shrimp farming is negatively impacting the water quality in coastal areas of Ha Long Bay. 
Nitrite and nitrate nitrogen: Nitrite and nitrate are products of nitrification processes in waters, whereby, ammonia is oxidized by aerobic, chemoautotrophic bacteria. Nitrite, a toxic substance for aquatic animals, normally exits at low levels in waters since it is usually converted into nitrate, the least toxic nitrogenous compound for aquatic animals, in the aerobic environment. Nitrite accumulates in waters when the rate of ammonia oxidation exceeds the rate of nitrite oxidation and the denitrification process of heterotrophic bacteria in anaerobic conditions (Boyd and Tucker, 1998). The concentrations of nitritenitrogen in creeks of this study were generally within the suggested level $\left(<0.055 \mathrm{mgL}^{-1}\right)$ of the Asian Working Group on Coastal and Marine Environment (AWGCME, 2009). At some study sites at IEC after shrimp crops, NO2-N levels were higher (maximum levels of $0.081 \mathrm{mg} \mathrm{L}^{-1}$ at $\mathrm{T} 1$ and $0.074 \mathrm{mg} \mathrm{L}^{-1}$ at T2). These higher levels most likely relate to high levels of ammonia, the substrate for nitrification process, in IEC as mentioned previously, or high levels of nitrite itself in shrimp farm effluent. However, these levels were lower than those found in effluent at high intensity shrimp farms reported by Samocha et al. (2004), Nguyen et al. (2007) and Nguyen (2008).

Nitrate-nitrogen concentrations in study creeks in Ha Long were lower in the first observation (T0) and this could be explained by lower rate of nitrification process at cooler temperatures and the rapid changes of water temperature between daytime and nighttime at that study time (Boyd and Tucker, 1998). After shrimp crops, NO3-N concentrations in study creeks, especially at IEC increased and this was the same pattern as ammonia changes in this study. The extremely high NO3-N concentrations in IEC at T2 may be due to the higher nitrification processes, which would reduce the TAN levels at this sampling time, as observed (Fig. 3a). The concentrations of NO3-N in this study were similar to those found in study of McNevin (2004) (0.00-0.63 $\mathrm{mg} \mathrm{L}^{-1}$, average of $0.31 \mathrm{mg} \mathrm{L}^{-1}$ ), but lower than those reported by Samocha et al. (2004) (average of 0.36$0.44 \mathrm{mg} \mathrm{L} \mathrm{L}^{-1}$ in influent and $0.45-0.67 \mathrm{mg} \mathrm{L}^{-1}$ in effluent). Compared with the guidelines of AWGCME (2009), NO3-N levels in study creeks, especially at sites surrounding concentrated shrimp farms in Ha Long area were higher than suggested levels $\left(<0.06 \mathrm{mg} \mathrm{L}^{-1}\right)$ for protecting aquatic life.

Total phosphorus: TP is a critically important factor that needs to be considered in the assessment and monitoring of coastal water quality relating to shrimp farming since it is the source of soluble inorganic phosphorus, the key metabolic nutrient for plant growth (Boyd and Green, 2002; Boyd and Tucker, 1998) and a major part of input phosphorus is not converted to shrimp biomass, but discharged into the surrounding environment (Briggs and Funge-Smith, 1994; FungeSmith and Briggs, 1998; Paez-Osuna et al., 1997; Teichert-Coddington et al., 2000; Xia et al., 2004; Paez-Osuna and Ruiz-Fernandez, 2005). TP concentrations at the ASF location in this study were normally lower than $0.05 \mathrm{mg} \mathrm{L}^{-1}$. The mean TP in IEC and OEC in this study were lower than those reported in study of Samocha et al. (2004) (means of 0.05-0.29 mg $\mathrm{L}^{-1}$ in influents and $0.15-0.51 \mathrm{mg} \mathrm{L}^{-1}$ in effluents). However, such TP levels can lead to eutrophication problem in coastal areas since TP levels of 0.001- 0.100 $\mathrm{mg} \mathrm{L^{-1 }}$ in coastal waters can cause phytoplankton blooms (Boyd and Green, 2002). Higher TP concentrations after shrimp crops, especially inside effluent creeks in this study indicated that shrimp farming activities can have a significant impact on receiving waterways in coastal areas of Ha Long Bay by stimulating algae blooms.

Dissolved orthophosphate: PO4-P concentrations in this study were generally lower than suggested levels $\left(<0.045 \mathrm{mg} \mathrm{L}^{-1}\right.$ for estuaries and $<0.015 \mathrm{mg} \mathrm{L}^{-1}$ for coastal waters) in the guidelines of AWGCME (2009) for protecting aquatic life although there was some variability among study times as well as IEC, OEC, ASF locations. PO4-P in waters normally accumulates at low concentrations in aquatic ecosystems due to its rapid uptake by plants or absorption by sediments; and some algae can absorb more dissolved orthophosphate than they need for growth and store it for later use (Boyd and Tucker, 1998).

Biochemical Oxygen Demand: BOD5 (5 day incubation at $20^{\circ} \mathrm{C}$ ) represents the oxygen consumption from the bacterial degradation of organic material in water; and therefore is useful as an indicator for organic pollution in monitoring and assessment of waterways (Boyd and Green, 2002; Clesceri and Franson, 1998). Boyd and Green (2002) suggested that BOD5 should below 5 or $6 \mathrm{mgO} 2 \mathrm{~L}^{-1}$ for protecting coastal aquatic ecosystems. In this study, BOD5 levels in most study sites were lower than suggested levels $\left(<5 \mathrm{mgO}_{2} \mathrm{~L}^{-1}\right)$. However, BOD5 levels inside effluent creeks increased after shrimp crops and at some study sites BOD5 levels exceeded the thresholds (i.e., maximum level of $7.23 \mathrm{mg}$ $\mathrm{L}^{-1}$ recorded at IEC, T2) indicating potential for organic pollution and eutrophication of receiving waterways.

Chemical oxygen demand: COD is the amount of oxygen required to completely oxidize all organic matters into carbon dioxide and water via the action of strong oxidizing agent; and thus it is recommended for water quality assessment for organic pollution as a simple and less time consuming method than BOD 
measurements (Nollet, 2000). High levels of COD reflect high concentrations of organic compounds in waters or the decline of aquatic ecosystem health. According to national technical regulation on coastal water quality (MONRE, 2008), the concentration of COD (KMnO4) should be below $3 \mathrm{mg} \mathrm{L}^{-1}$ in coastal aquaculture and preservation zones. In this study, COD levels at concentrated shrimp farming areas were normally higher than the allowable limits, especially at study sites surrounding shrimp farms. Similar to BOD levels found in this study, COD concentrations were higher inside effluent creeks and increased after shrimp crops, meaning that shrimp farm effluent has impacted water quality of receiving waterways through the discharge of excess organic matter. The levels of COD at ASF locations in this study were similar to those found in inlet creeks for intensive farming areas in Eastern China (mean of $4.72 \mathrm{mg} \mathrm{L}^{-1}$ ) (Biao et al., 2004); however, COD levels in IEC and OEC were much higher than that of effluent creeks in their study (mean of $5.77 \mathrm{mg} \mathrm{L}^{-1}$ ). COD levels in this study, however, were much lower than those found by Nguyen (2008) (means of 14.7-58.9 $\mathrm{mg} \mathrm{L}^{-1}$ at different areas) in their study in Can Gio, Ho Chi Minh City, Vietnam because their study areas were impacted by both shrimp farm effluent as well as urban pollution.

Chlorophyll-a: Chl-a refers to phytoplankton biomass as it constitutes about 1-2\% dry weight of all algae and cyanobacteria and is often used as an indicator of the trophic status, or level of pollution, of an aquatic ecosystem (ANZECC-ARMCANZ, 2000; Boyd and Green, 2002). Chl-a concentration varies in water bodies depending on nutrient levels, light intensity and water temperature for the growth of aquatic plants (Boyd and Tucker, 1998). Guerrero-galvan et al. (1998) and Tapia Gonzalez et al. (2008) also found seasonal differences of Chl-a levels in shrimp farms as well as coastal lagoons in tropical regions, in which Chl-a during the rainy, summer season was normally higher than that of dry, winter season. A similar seasonal pattern was observed in this study (Fig. 4d). Chl-a concentrations were extremely high in effluent creeks after shrimp crops. This indicated that shrimp farms released high levels of algae biomass as well as nutrients for algal growth in receiving waterways. Compared with previous studies, Chl-a concentrations in Ha Long area (0.54-36.09 $\left.\mu \mathrm{g} \mathrm{L}^{-1}\right)$ were similar to those reported by McNevin (2004) in his study in Mahajamba Bay, receiving shrimp farm effluent (0.00$38.08 \mu \mathrm{g} \mathrm{L}^{-1}$ ) but lower than those found in shrimp farming areas in Honduras (means of 33-64 $\mu \mathrm{g} \mathrm{L}^{-1}$ in embayment intake waters and 74-75 $\mu \mathrm{g} \mathrm{L}^{-1}$ in estuary intake waters) (Teichert-Coddington et al., 2000) and in outflow of shrimp ponds in New Caledonia (from 15.1 $\pm 15.5-30.2 \pm 32.6 \mu \mathrm{g} \mathrm{L}^{-1}$ ) (Lemonnier and Faninoz, 2006) and in creek receiving shrimp effluent in Queensland, Australia (from 7.3 \pm 6.9-50.4 $\pm 38.7 \mu \mathrm{g}$ $\mathrm{L}^{-1}$ ) (Trott and Alongi, 2000). Referring to the suggested level by Boyd and Green (2002) (above 1-10 $\mu \mathrm{g} \mathrm{L} \mathrm{L}^{-1} \mathrm{Chl}-\mathrm{a}$ indicate the eutrophication of coastal waters), there is a signal of eutrophication at concentrated shrimp farming areas in Ha Long bay.

Total suspended solids: TSS is assessed in coastal water bodies because it indicates the concentration of suspended soil particles and suspended organic matter in water and it should not change by more than $10 \%$ of the seasonal mean in coastal waters if aquatic ecosystems are to be protected (Boyd and Green, 2002). A major concern relating to coastal shrimp farming activity is the reduction of vegetation, resulting in the increased erosion throughout the region, as well as the discharge of waste feed, faeces in shrimp farm effluent, which leads to increased TSS levels in surrounding waterways. In this study, TSS levels did not vary greatly among IEC, OEC, ASF locations (except T1), with the major variation being associated with seasonal changes. Some extreme TSS levels (152, 267, $270 \mathrm{mg}$ $\mathrm{L}^{-1}$ ) detected at T0 were caused by sand dredging by boats near that study sites. The increase of TSS after shrimp crops may be due to organic particles in shrimp farm effluent as well as a seasonal aspect, with increased soil particles during the wet season. However, higher concentrations of TSS in IEC, in comparison with ASF, especially after shrimp crop 1 indicated that shrimp farms discharged high levels of waste feed and faeces into surrounding environment after the main crop (T1). High levels and wide variation of TSS in this study were similar to those reported in study of McNevin (2004) (3.0-764 mg L $\mathrm{m}^{-1}$. Referring to the national standard for coastal water quality at aquaculture and preservation zones $\left(<50 \mathrm{mg} \mathrm{L}^{-1}\right)$ (MONRE, 2008), TSS levels in this study were very high providing further evidence of degradation of the coastal ecosystem in Ha Long.

\section{CONCLUSION}

The findings of this study are consistent with a number of other studies that have reached similar conclusions concerning the environmental impacts of shrimp farming in many part of the world (Biao et al., 2004; Costanzo et al., 2004; Guerrero-galvan et al., 1998; Islam et al., 2004; McNevin, 2004; Nguyen, 
2008; Samocha and Lawrence, 1995; Samocha et al., 2004; Tookwinas, 1998; Trott and Alongi, 2000). Spatial variation in water quality was found with the most degraded aquatic environments being in the effluent channels, creeks at concentrated shrimp farms with impacts on the receiving waters adjacent to the shrimps, with these impacts declining in the same creeks 1-2 km away from the points of effluent discharge. Water quality was also found to change seasonally with degraded water quality most apparent in summer after the first shrimp harvest. The water quality parameters indicate that eutropication, linked to shrimp farm discharge, is occurring and steps need to be taken to limit these effects. Thus it would be undesirable for the shrimp farming industry to expand or intensify further in this region. Steps to reduce shrimp stocking and feeding rates and to improve the quality of shrimp feed to reduce the nutrient loadings in ponds should be an urgent objective for management and research (Tucker and Hargreaves, 2009; FAO-NACA-UNEP-WB-WWF, 2006).

If the special ecological and biodiversity values of the Ha Long Bay world heritage area to be preserved for the long term, this study needs to be expanded to include sampling of a greater range of aquatic sites and variables. This will allow a more comprehensive description of water quality variability, identification of areas subject to degradation and thereby support science-based management of shrimp farming and other aquaculture activities, the protection of aquatic life and human health.

\section{ACKNOWLEDGEMENT}

The researchers gratefully acknowledge the Endeavour Awards Program, DEEWR, Australia for an Endeavour Postgraduate Award. This research was made possible thanks to Charles Darwin University for fieldtrip financial and technical support. Special thanks go to the Center for Environment and Disease Monitoring in Aquaculture, Research Institute for Aquaculture No1, Vietnam for equipment and lab support. We also would like to thank our colleagues in Vietnam for their assistance during fieldwork.

\section{REFERENCES}

Anh, P.T., C. Kroeze, S.R. Bush and A.P.J. Mol, 2010. Water pollution by intensive brackish shrimp farming in south-east Vietnam: Causes and options for control. Agr. Water Manage., 97: 872-882. DOI: 10.1016/j.agwat.2010.01.018
ANZECC-ARMCANZ, 2000. Australian and New Zealand Guidelines for Fresh and Marine Water Quality. Australian and New Zealand Environment and Conservation Council and Agriculture and Resource Management Council of Australia and New Zealand, Canberra. ISBN: 0957824505

Clesceri, L.S. and M.A.H. Franson, 1998. Standard Methods for the Examination of Water and Wastewater. 20th Edn., American Public Health Association, Washington D.C., pp: 1220.

AWGCME, 2009. The Marine Water Quality Criteria for the ASEAN Region. AWGCME.

Biao, X., D. Zhuhong and W. Xiaorong, 2004. Impact of the intensive shrimp farming on the water quality of the adjacent coastal creeks from Eastern China. Marine Poll. Bulletin, 48: 543-553. DOI: 10.1016/j.marpolbul.2003.10.006

Tucker, C.S. and J.A. Hargreaves, 2009. Environmental Best Management Practices for Aquaculture. 1st Edn., John Wiley and Sons, Ames, IA., ISBN: 0813802784, pp: 592.

Boyd, C.E. and B.W. Green, 2002. Coastal water quality monitoring in shrimp farming areas, an example from Honduras. Consortium Program on Shrimp Farming and the Environment. Word Bank, NACA, WWF, FAO.

Boyd, C.E. and C.S. Tucker, 1998. Pond Aquaculture Water Quality Management. 1st Edn., Boston, Kluwer Academic, London, ISBN-10: 0412071819, pp: 700.

Briggs, M.R.P. and S.J. Funge-Smith, 1994. A nutrient budget of some intensive marine shrimp ponds in Thailand. Aquac. Fisheries Manage., 25: 789-811. DOI: 10.1111/j.1365-2109.1994.tb00744.x

Costanzo, S.D., M.J. O'Donohue and W.C. Dennison, 2004. Assessing the influence and distribution of shrimp pond effluent in a tidal mangrove creek in north-east Australia. Marine. Poll. Bull., 48: 514525. DOI: 10.1016/j.marpolbul.2003.09.006

CTCC, 2008. Report of adjustment of the masterplan for fishery in Quang Ninh province in 2007 - 2010 and orientations towards 2020. Construction and Trading Consultant Joint-Stock Company, Ha Long.

Dierberg, F. and W. Kiattisimkul, 1996. Issues, impacts and implications of shrimp aquaculture in Thailand. Environ. Manage., 20: 649-666. DOI: 10.1007/BF01204137

Doan, B., 2001. Marine Chemistry: Methods of Seawater Analysis. Vietnam National University, Hanoi. 
DoF Quang Ninh, 2001. Masterplan for fishery development of Quang Ninh province. Fishery Department of Quang Ninh Province, Ha Long.

DoF Quang Ninh, 2005. Report of the imlementation of plans for concentrated aquaculture areas in Quang Ninh province. Fishery Department of Quang Ninh Province, Ha Long.

Ennos, R., 2007. Statistical and Data Handling Skills in Biology. 2nd Edn., Harlow, Pearson Prentice Hall, Engl, Toronto, ISBN-10: 0131955845, pp: 235.

EPA-Victoria, 2001. Water quality objectives for marine and estuarine waters-ecosystem protection. Southbank-Victoria. Environment Protection Authority Victoria. FAO-NACA-UNEP-WBWWF, 2006. International principles for responsible shrimp farming. Shrimp Farming and Enviornment.

FAO, 2010. FAO Yearbook, Fishery and Aquaculture Statistics. 1st Edn., Food and Agriculture Organization of the United Nations, Rome, ISBN: 9789250066981, pp: 72.

Field, A.P., 2009. Discovering Statistics Using SPSS. 3rd Edn., Sage Publications Ltd., Los Angeles, London, ISBN-10: 1847879071, pp: 821.

Flaherty, M. and C. Karnjanakesorn, 1995. Marine shrimp aquaculture and natural resource degradation in Thailand. Environ. Manage., 19: 2737. DOI: 10.1007/BF02472001

Funge-Smith, S.J. and M.R.P. Briggs, 1998. Nutrient budgets in intensive shrimp ponds. implications for sustainability. Aquaculture, 164: 117-133. DOI: 10.1016/S0044-8486(98)00181-1

Gonzalez, F.U.T., J.A. Herrera-Silveira and M.L. Aguirre-Macedo, 2008. Water quality variability and eutrophic trends in karstic tropical coastal lagoons of the Yucatan Peninsula. Estuarine, Coastal Shelf Sci., 76: 418-430. DOI: 10.1016/j.ecss.2007.07.025

GSOV, 2009. Statistical Yearbook of Vietnam. Statistical Publishing House, Hanoi.

Graham, R.C., 1993. Data Analysis for the Chemical Sciences: A Guide to Statistical Techniques, 1st Edn., VCH, New York, ISBN-10: 1560810483, pp: 536.

Graslund, S., K. Holmstrom and A. Wahlstrom, 2003. A field survey of chemicals and biological products used in shrimp farming. Marine Poll. Bull., 46: 8190. DOI: 10.1016/S0025-326X(02)00320-X

Guerrero-Galvan, S.R., F. Paez-osuna, A.C. Ruizfernandez and R. Espinoza-Angulo, 1998. Seasonal variation in the water quality and chlorophyll a of semi-intensive shrimp ponds in a subtropical environment. Hydrobiologia, 391: 33-45. DOI: 10.1023/A:1003590625379
Hibbert, D.B. and J.J. Gooding, 2006. Data Analysis for Chemistry: An Introductory Guide for Students and Laboratory Scientists. 1st Edn., Oxford University Press, New York, ISBN: 0195162102, pp: 177.

Islam, S.M., J.M. Sarker, T. Yamamoto, A.M. Wahab and M. Tanaka, 2004. Water and sediment quality, partial mass budget and effluent $\mathrm{N}$ loading in coastal brackishwater shrimp farms in Bangladesh. Marine Poll. Bull., 48: 471-485. DOI: 10.1016/j.marpolbul.2003.08.025

Jackson, C., N. Preston, P.J. Thompson and M. Burford, 2003. Nitrogen budget and effluent nitrogen components at an intensive shrimp farm. Aquaculture, 218: 397-411. DOI: 10.1016/S00448486(03)00014-0

Jones, A.B., M.J. O'Donohue, J. Udy and W.C. Dennison, 2001. Assessing ecological impacts of shrimp and sewage effluent: Biological indicators with standard water quality analyses. Estu. Coastal Shelf Sci., 52: 91-109. DOI: 10.1006/ecss.2000.0729

Lemonnier, H. and S. Faninoz, 2006. Effect of water exchange on effluent and sediment characteristics and on partial nitrogen budget in semi-intensive shrimp ponds in New Caledonia. Aquacul. Res., 37: 938-948. DOI: 10.1111/j.1365-2109.2006.01515.x

Martin, J.L.M., Y. Veran, O. Guelorget and D. Pham, 1998. Shrimp rearing: stocking density, growth, impact on sediment, waste output and their relationships studied through the nitrogen budget in rearing ponds. Aquaculture, 164: 135-149. DOI: 10.1016/S0044-8486(98)00182-3

McNevin, A.A., 2004. Water Quality Monitoring of Mahajamba Bay, Madagascar. 1st Edn., Auburn University, pp: 244. MONRE., 2008. National technical regulation on costal water quality (QCVN10:2008/BTNMT). Ministry of Natural Resources and Environment (Decision No.16/2008/QD-BTNMT), Hanoi.

Nguyen, V.T., 2008. The influences of shrimp farming and fishing practices on natural fish conservation in Can Gio, Ho Chi Minh City, Vietnam. Ph.D. Thesis, University of Newcastle.

Nguyen, V.T., S. Momtaz and K. Zimmerman, 2007. Water pollution concerns in shrimp farming in Vietnam. A case study of Can Gio, Ho Chi Minh city. Int. J. Environ. Cultural, Econ. Soc. Sustain., 3: $129-138$

Nollet, L.M.L., 2000. Handbook of Water Analysis. 1st Edn., CRC Press, New York, ISBN: 0824784332, pp: 920. 
Paez-Osuna, F., S.R. Guerrero-Galvan, A.C. RuizFernandez and R. Espinoza-Angulo, 1997. Fluxes and mass balances of nutrients in a semi-intensive shrimp farm in north-western Mexico. Marine Poll. Bulletin, 34: 290-297. DOI: 10.1016/S0025326X(96)00133-6

Paez-Osuna, F., S.R. Guerrero-Galvan and A.C. RuizFernandez, 1998. The environmental impact of shrimp aquaculture and the coastal pollution in Mexico. Marine Poll. Bulletin, 36: 65-75. DOI: 10.1016/S0025-326X(98)90035-2

Paez-Osuna, F., 2001. The environmental impact of shrimp aquaculture. Causes, effects and mitigating alternatives. Environ. Manage., 28: 131-140. DOI: 10.1007/s002670010212

Paez-Osuna, F., A. Gracia, F. Flores-Verdugo, L.P. Lyle-Fritch and R. Alonso-Rodriguez et al., 2003. Shrimp aquaculture development and the environment in the Gulf of California ecoregion. Marine Poll. Bulletin, 46: 806-815. DOI: 10.1016/S0025-326X(03)00107-3

Paez-Osuna, F. and A.C. Ruiz-Fernandez, 2005. Environmental load of nitrogen and phosphorus from extensive, semiintensive and intensive shrimp farms in the Gulf of California ecoregion. Bulletin Environ. Contam. Toxic., 74: 681-688. DOI: 10.1007/s00128-005-0637-8

PCQNP, 2010. Quang ninh portal. Quangninh Department of Information and Communications, Ha Long.

Quinn, G.P. and M.J. Keough, 2002. Experimental Design and Data Analysis for Biologists. 1st Edn., Cambridge University Press, Cambridge, ISBN: 0521009766, pp: 537.

Rodriguez-Gallego, L., E. Meerhoff, L. Poersch, L. Aubriot and C. Fagetti, et al., 2008. Establishing limits to aquaculture in a protected coastal lagoon: Impact of Farfantepenaeus paulensis pens on water quality, sediment and benthic biota. Aquaculture, 277: 30-38. DOI: 10.1016/j.aquaculture.2007.12.003

Samocha, T.M. and A.L. Lawrence, 1995. Shrimp farms' effluent waters, environmental impact and potential treatment methods. UJNR Technical Report No 24.
Samocha, T.M., I.M. Lopez, E.R. Jones, S. Jackson and A.L. Lawrence, 2004. Characterization of intake and effluent waters from intensive and semiintensive shrimp farms in Texas. Aqua. Res., 35: 321-339. DOI: 10.1111/j.1365-2109.2004.01002.x

Senarath, U. and C. Visvanathan, 2001. Environmental issues in brackish water shrimp aquaculture in Sri Lanka. Environ. Manage., 27: 335-348. DOI: 10.1007/s002670010153

Teichert-Coddington, D.R., D. Martinez and E. Ramirez, 2000. Partial nutrient budgets for semiintensive shrimp farms in Honduras. Aquaculture, 190: 139-154. DOI: $10.1016 /$ S00448486(00)00389-6

Thakur, D.P. and C.K. Lin, 2003. Water quality and nutrient budget in closed shrimp (Penaeus monodon) culture systems. Aquac. Eng., 27: 159176. DOI: 10.1016/S0144-8609(02)00055-9

Tookwinas, S., 1998. The environmental impact of intensive marine shrimp farming effluents and carrying capacity estimation at Kung Krabaen Bay, Eastern Thailand. Asian Fisheries Sci., 11: 303-316.

Trott, L.A. and D.M. Alongi, 2000. The impact of shrimp pond effluent on water quality and phytoplankton biomass in a tropical mangrove estuary. Marine Pollution Bull., 40: 947-951. DOI: 10.1016/S0025-326X(00)00035-7

UNESCO, 2010. UNESCO World heritage list. United Nation Education Scientific and Cultural Organization

US-EPA, 2001. Nutrient criteria technical guidance manual estuarine and coastal marine water. U.S. Environmental Protection Agency, Office of Water.

Xia, L.Z., L.Z. Yangans and M.C. Yan, 2004. Nitrogen and phosphorus cycling in shrimp ponds and the measures for sustainable management. Environ. Geoch. Health, 26: 245-251. DOI: 10.1023/B:EGAH.0000039587.64830.43

Zar, J.H., 1999. Biostatistical Analysis. 4th Edn., Prentice Hall, New Jersey, ISBN-10: 013081542X. pp: 663.

Zuur, A.F., E.N. Ieno and G.M. Smith, 2007. Analysing Ecological Data. Berlin, Springer, New York, ISBN-10: 0387459677. pp: 672. 